TITLE:

\title{
Sediment-complex-binding cellulose breakdown in wetlands of rivers
}

AUTHOR(S):

Liu, Wen; Toyohara, Haruhiko

CITATION:

Liu, Wen ... [et al]. Sediment-complex-binding cellulose breakdown in wetlands of rivers. Fisheries Science 2012, 78(3): 661-665

ISSUE DATE:

2012-05

URL:

http://hdl.handle.net/2433/156153

\section{RIGHT:}

The final publication is available at www.springerlink.com; This is not the published version. Please cite only the published version.; この論文 は出版社版でありません。引用の際には出版社版をご確認ご利用くだ さい。 
和文要旨

河川底泥成分に吸着したセルロース分解活性

劉 文，豊原治彦（京大院農）

東海、近畿及び九州地方の 5 河川（筑後川，緑川，浜戸川，淀川，田中川）の 河口域湿地帯から採集した底泥のセルラーゼ活性を測定した結果、活性レベル は河川により異なっていた。抗生物質で殺菌処理しても底泥は強いセルラーゼ 活性を示したことから，セルラーゼの底泥成分への吸着が推測された。上記 5 河川の底泥のカビ由来セルラーゼの吸着能には違いがあったが，それは底泥中 の植物残渣量の違いによるものと考えられた。本研究は、河川底泥においてセ ルラーゼが植物残渣等の底泥成分に吸着して分解機能を発現している可能性を 示唆した。

キーワード : 湿地帯、底泥、セルラーゼ、泥、植物残渣 
1 Sediment-complex-binding cellulose breakdown in wetlands of rivers

2

3 Wen $\mathrm{Liu}^{1} \cdot$ Haruhiko Toyohara ${ }^{1} *$

4

$5{ }^{1}$ Division of Applied Biosciences, Graduate School of Agriculture, Kyoto University,

6 Kyoto 606-8502, Japan

7

8 Corresponding author

$9 \quad$ Haruhiko Toyohara

10 Tel/Fax: 81-075-753-6446

11 Email: toyohara@kais.kyoto-u.ac.jp 
12 Abstract We have been assessing the activity level of cellulase in wetland sediments

13 to clarify the significance of cellulase for the turnover of plant cellulose in wetlands. In

14 the present study, we investigated the cellulose degrading function of sediment in

15 wetlands to clarify the biochemical breakdown mechanism of cellulose. Specifically, we

16 measured cellulase activities of sediments collected from wetlands of the Chikugo River

17 (Fukuoka Prefecture), Midori River (Kumamoto Prefecture), Hamado River

18 (Kumamoto Prefecture), Yodo River (Osaka Prefecture), and Tanaka River (Mie

19 Prefecture). The results revealed that the activity levels differed significantly among

20 rivers. Additionally, the cellulase activities of the sediment were not completely

21 suppressed in the presence of chloramphenicol. These findings suggested that a portion

22 of the cellulase activities were derived from cellulases binding to the components of

23 sediments. Actually, sediments also showed the ability to bind fungal cellulase.

24 Comparison of the binding ability of clay and plant residues, the main components of

25 sediments, revealed that plant residues had significantly higher abilities to bind cellulase.

26 This finding was supported by the fact that there was a strong correlation between the

27 organic matter content in the sediment and the cellulase binding ability $(R=0.66)$.

28 Results of the present study show that sediment complexes harboring cellulases might

29 be function as a bioreactor to degrade cellulose in wetlands.

30 Keywords Bioreactor $\cdot$ Cellulase $\cdot$ Clay $\cdot$ Plant residue $\cdot$ River $\cdot$ Sediment $\cdot$ Wetland 


\section{Introduction}

34 Cellulose is the main component of the cell walls of plants. Cellulose that is transported

35 from forests to wetlands by rivers is assumed to be utilized by a variety of organisms as

36 a carbon source $[1,2,3,4,5,6]$; however, the details of the degradation process of

37 cellulose in wetlands remain unknown.

Cellulose is a high molecular weight polysaccharide comprised of glucose

39 bound by $\beta-1,4$ linkage that is biochemically stable when compared with starch, in

40 which glucose is bound by $\alpha-1,4$ linkage and $\alpha-1,6$ linkage. Accordingly, a series of

41 enzymes such as endo- $\beta$-glucanase, cellobiohydrolase, and $\beta$-glucosidase, which are

42 collectively designated as cellulases, are required for the enzymatic breakdown of 43 cellulose [7].

$44 \quad$ Until recently, it has been assumed that herbivores digest cellulose using

45 cellulases derived from the symbiotic microorganisms [8]. Moreover, cellulases in

46 invertebrates, including insects, were long been assumed to originate from symbiotic

47 microbes before demonstration of the endogenous origin of termite cellulase [9]. During

48 the last decade, cellulase genes have been reported in the aquatic organisms such as

49 crayfish [1], mussel [2], abalone [3], bivalve [4], and sea urchin [5].

In addition to these macrobenthos, other organisms such as meiobenthos, fungi,

51 and bacteria are expected to be involved in the degradation of cellulose in the sediments 
52 of wetlands $[6,10,11]$. In the present study, we attempted to identify organisms

53 contributing to the degradation of cellulose in sediments. The results revealed that

54 cellulases derived from organisms are bound to the components of sediments such as

55 clay and plant residues. Overall, the results of the present study suggest that sediments

56 in wetlands function as a bioreactor to degrade cellulose.

57

\section{Materials and Methods}

60 Collection of sediments

62 Sediments from the Tanaka River (Mie Prefecture) were collected on October 20, 2009

63 and September 8, 2010. Sediments from the Yodo River (Osaka Prefecture) were

64 collected on September 23, 2009. Sediments from the Chikugo River (Fukuoka

65 Prefecture), Hamado River (Kumamoto Prefecture), and Midori River (Kumamoto

66 Prefecture) were collected on October 29, 2010. We selected one collecting site within

$6750 \mathrm{~m}$ from the river mouth and transported these samples at $4^{\circ} \mathrm{C}$ back to the laboratory

68 at Kyoto University. Sediment samples were stored at $4^{\circ} \mathrm{C}$ until analyses. Macrobenthos

69 such as bivalves and crustaceans were removed prior to collection of the sediments.

70 Upon arrival at the laboratory, meiobenthos such as nematodes and oligochaetes were

71 carefully removed using tweezers in conjunction with microscopic observation

72 (OLYMPUS-SZX12, OLYMPUS, Tokyo, Japan). To remove the meiobenthos 
73 completely, the sediments were further filtered through a $63 \mu \mathrm{m}$ mesh and the

74 pass-through fraction was used for the subsequent experiments.

76 Measurement of cellulase activity of sediments

77

78 The cellulase activities of sediments collected from rivers were estimated by measuring

79 reducing sugar released from carboxymethyl cellulose (CMC, Sigma, St. Louis, MO,

80 USA) according to the method described by Somogyi-Nelson [12]. Briefly, $5.0 \mathrm{~g}$ of

81 sediment were mixed with $0.5 \mathrm{ml}$ toluene, $10 \mathrm{ml}$ of $0.2 \mathrm{M}$ sodium acetate buffer (pH 5.9)

82 and $10 \mathrm{ml}$ of $1 \% \mathrm{CMC}$ solution. The $\mathrm{CMC}$ was dissolved in water to give a $1 \%$ solution.

83 For the blank, water was used instead of $\mathrm{CMC}$ solution. Following incubation at $30^{\circ} \mathrm{C}$

84 for $24 \mathrm{~h}$, the reaction mixture was centrifuged for $10 \mathrm{~min}$ at 2,500×g and $1 \mathrm{ml}$ of the

85 supernatant was then transferred to another tube and combined with $1 \mathrm{ml}$ of Somogyi

86 solution (1.2\% $\mathrm{KNaC}_{4} \mathrm{H}_{4} \mathrm{O}_{6} \cdot 4 \mathrm{H}_{2} \mathrm{O}, 2.4 \% \mathrm{Na}_{2} \mathrm{CO}_{3}, 0.4 \% \mathrm{CuSO}_{4}, 1.6 \% \mathrm{NaHCO}_{3}, 18 \%$

$87 \mathrm{Na}_{2} \mathrm{SO}_{4}$ ). The mixture was then incubated at $100^{\circ} \mathrm{C}$ for $10 \mathrm{~min}$. Next, the samples were

88 cooled with cold water, then $1 \mathrm{ml}$ of Nelson solution $\left(1.2 \%\left(\mathrm{NH}_{4}\right)_{6} \mathrm{Mo}_{7} \mathrm{O}_{24} \cdot 4 \mathrm{H}_{2} \mathrm{O}, 0.15 \%\right.$

$\left.89 \mathrm{Na}_{2} \mathrm{HAsO}_{4} \cdot 7 \mathrm{H}_{2} \mathrm{O}, 4.2 \% \mathrm{H}_{2} \mathrm{SO}_{4}\right)$ and $18 \mathrm{ml}$ of water were added. The absorbance at 600

$90 \mathrm{~nm}$ was then measured using a spectrophotometer (UV-mini-1240, Shimadzu, Kyoto,

91 Japan) and the activity was represented as the reducing sugar released by $1 \mathrm{~g}$ of

92 sediment for $1 \mathrm{~h}[12]$. Unless otherwise specified, reagents of specific grades were

93 purchased from nacalai tesque (Kyoto, Japan). 
94

95 Effect of chloramphenicol on cellulase activity of sediments

97 microorganisms, the effects of antibiotics on the cellulase activity of the sediments were

98 investigated. As a preliminary experiment, the effects of ampicillin, kanamycin,

99 tetracycline, and chloramphenicol on the growth of microorganisms in the sediment
To determine if cellulase activity detected in the sediments was derived from $\mathrm{mg}$, or $4 \mathrm{mg}$ of ampicillin, kanamycin, tetracycline, or chloramphenicol per gram of wet sediment, after which they were incubated at $37^{\circ} \mathrm{C}$ for $24 \mathrm{~h}$. The effects of antibiotics were evaluated by plating the incubated sediments on LB (Luria Bertani medium) plates and incubating for five days. Only chloramphenicol (400 mg and $40 \mathrm{mg}$ per $1 \mathrm{~g}$ sediment) completely inhibited the growth of the microorganisms including bacteria and fungi. Thus, we selected chloramphenicol to sterilize microorganisms in the sediments.

A solution of $2 \mathrm{ml}$ of chloramphenicol dissolved in $50 \%$ ethanol to give 100 $\mathrm{mg} / \mathrm{ml}$ was added to $5 \mathrm{~g}$ of per gram of wet sediment collected from the Tanaka and Midori Rivers, which gave $40 \mathrm{mg}$ chloramphenicol per gram of wet sediment in a final concentration. These samples were then incubated for $24 \mathrm{~h}$ at $30^{\circ} \mathrm{C}$. As a control, $2 \mathrm{ml}$ of $50 \%$ ethanol in water was added. After incubation, the sediment was spread on a LB plate to validate the sterilizing effect of chloramphenicol on microorganisms. Meanwhile the sediment was spread on $\mathrm{CMC}$ agar plates containing $1 \% \mathrm{CMC}$, $0.15 \% \mathrm{Ca}\left(\mathrm{NO}_{3}\right)_{2}, 0.05 \% \mathrm{MgSO}_{4}, 0.05 \% \mathrm{~K}_{2} \mathrm{HPO}_{4}$ and $1.5 \%$ agar and the samples were then incubated at $30^{\circ} \mathrm{C}$ for three days to detect the remaining cellulase activity of the 
116 sediment (data not shown). Then, the remaining cellulase activities of the two rivers

117 were quantified by Somogyi Nelson method described above [12].

119 Evaluation of cellulase binding ability of sediments

120 Sediments collected from all rivers were autoclaved at $121^{\circ} \mathrm{C}$ for 15 min to inactivate

121 sediment-bound cellulases after vigorous washing with water. After cooling, the

122 following procedures were conducted in the clean bench. Two grams (dry weight) of

123 autoclaved sediment and $6.25 \mathrm{mg}$ of Aspergillus niger cellulase (MP Biomedicals,

124 California, USA) dissolved in $5 \mathrm{ml} \mathrm{H}_{2} \mathrm{O}$ were mixed and shaken for $1 \mathrm{~h}$ at room

125 temperature to bind the cellulase to the sediments. After centrifugation at $2,500 \times g$ for

$12610 \mathrm{~min}$, the pellet was vigorously washed twice with excess water to remove the

127 unbound cellulase. The cellulase activities of the sediments were measured as described

128 above to determine cellulase binding ability. The activity was expressed as the reducing 129 sugar released per dry weight of sediments.

131 Comparison of cellulase binding ability between clay and plant residues

133 Sediments collected from the Midori River were separated into clay and plant residues

134 using tweezers in conjunction with microscopic observation. To inactivate the originally

135 bound cellulase, separated clay and plant residues were autoclaved for $121^{\circ} \mathrm{C}$ for $15 \mathrm{~min}$.

136 Next, the commercially obtained fungal cellulase and autoclaved clay or plant residues 
137 were mixed for $1 \mathrm{~h}$ at room temperature as described above. After washing vigorously

138 with an excess amount of water, the cellulase activities bound to clay and plant residues

139 were measured, respectively. The activity was expressed as the reducing sugar released

140 per dry weight of clay or plant residues.

142 Correlation between organic matter content and cellulase binding ability

144 Sediments were heated at $600^{\circ} \mathrm{C}$ for $3 \mathrm{~h}$ using a mantle heater (KCA-10A, Koito, Tokyo,

145 Japan). The organic matter content was determined based on the loss on ignition values.

146 The correlation between the cellulase binding ability determined in Table 3 and the

147 organic matter content was then estimated.

149 Statistical analyses

150 All data were statistically analyzed by ANOVA.

151

152 Results

153 Cellulase activity of sediments from five rivers

154 As shown in Table 1, sediments collected from all five rivers exhibited cellulase

155 activities. However, the activity levels differed among rivers. Specifically, sediments 
156 from the Yodo River showed significantly higher activity than those from the Hamado

157 River, Midori River and Tanaka River, while those from the Chikugo River had higher

158 values than those from the Midori River and Tanaka River. Sediments from the Hamado

159 River showed significantly higher activity than those from the Tanaka River. However,

160 the activity levels differed among rivers so far as compared by using the data obtained

161 from the collecting sites of each river.

162

163 Effect of chloramphenicol on the cellulase activity of sediment

165 As shown in Table 2, chloramphenicol exhibited no effect on the cellulase activity of

166 sediment from the Midori River, while it showed a partially inhibiting effect on that of

167 the Tanaka River. These findings suggest that part of the cellulase activity of the Tanaka

168 River was derived from microorganisms sensitive to chloramphenicol. It should be

169 stressed that a substantial amount of the activity of sediments from both rivers remained,

170 even in the presence of chloramphenicol, suggesting that these activities were derived

171 from cellulases extracellularly secreted from microorganisms and /or benthic animals.

173 Binding of fungal cellulase to the sediments

174 The finding above suggested us that cellulases secreted from organisms would directly

175 bind to sediments under natural condition. To validate this, we examined the binding

176 ability of sediments to commercial available fungal cellulase. As shown in Table 3, 
177 sediments collected from all five rivers showed fungal cellulase binding ability (Table

178 3). The sediments from Tanaka River showed significantly lower binding ability than

179 those from Hamado River and Chikugo River, while those from Yodo River showed

180 lower binding ability than those from Chikugo River.

181 The finding clearly suggested that sediment has the ability to bind cellulase.

182 Sediments are mainly composed of clay and plant residues. Thus, we subsequently

183 compared the cellulase binding ability between clay and plant residues using sediment

184 collected from the Midori River. The result revealed that $11.7 \pm 2.3 \mu \mathrm{g} / \mathrm{g}$ of cellulase

185 was bound to clay, while $419.5 \pm 47.1 \mu \mathrm{g} / \mathrm{g}$ of cellulase was bound to plant residues.

186 These results suggest that plant residues have significantly higher $(P<0.05)$ cellulase

187 binding ability than clay.

189 Correlation between organic matter content and cellulase binding ability

190 As shown in Fig. 1, the organic matter content varied among rivers. Organic matter in

191 sediment was assumed to primarily consist of plant residues. For example, sediment

192 from the Midori River included a large content of plant resides (14.2\%), while that of

193 the Tanaka River included a small amount of plant residues (1.3\%). A strong correlation

194 between cellulase binding ability and the organic matter content in the sediments was 
195 also observed $(R=0.66)$, suggesting that plant residues can function as an efficient

196 binder of cellulase in the sediment.

\section{Discussion}

A significant amount of cellulase activities remained in the presence of

199 chloramphenicol (Table 2). When sediments incubated in the presence of

200 chloramphenicol were inoculated onto agar plates containing LB medium without

201 chloramphenicol, no colonies of microorganisms (fungi or bacteria) were observed

202 during incubation for five days (data not shown), suggesting that microorganisms in the

203 sediment were completely attenuated by chloramphenicol. Based on these findings, we

204 assumed that sediment-complex-binding cellulases secreted from microorganisms

205 and/or benthic animals function as a bioreactor independent of organisms under natural

206 conditions.

207

High cellulase activities of sediments in the Yodo River and Chikugo River

208 were detected, while low activity was observed for the Tanaka River (Table 1). This is

209 because sediments from the Tanaka River showed low cellulase binding ability,

210 possibly due to the low content of plant residues (Table 3 and Fig. 1). The cellulase

211 activity in sediment from the Midori River was significantly lower than that of the Yodo 
212 River (Table 1), although the cellulase binding ability of the sediment from the Midori

213 River was not significantly different from Yodo River (Table 3). As described above,

214 these results suggest that a significant amount of cellulase was secreted extracellularly

215 from microorganisms and/or benthic animals. Accordingly, these findings strongly

216 suggest that the low cellulase activity in sediment of the Midori River could be ascribed

217 to the low level of cellulase supplied by microorganisms and/or benthic animals.

218 The results shown in Table 3 suggest that river sediments have cellulase binding

219 ability but that the level differed among rivers. As shown in Fig.1, the cellulase binding

220 ability of sediments depends on the content of plant residues. Indeed, there was a strong

221 correlation between the organic matter content in the sediments and cellulase binding

222 abilities $(R=0.66)$. Organic materials in sediments were considered to be almost

223 entirely a result of plant residues because no weight loss was observed before and after

224 heat treatment of sediments from which the plant residues were removed by tweezers as

225 possible as carefully (data not sown). The difference in the level of cellulase activity of

226 the sediments of various rivers could be ascribed to the content of plant residues as well

227 as the content of cellulase supplied by microorganisms and/or benthic animals. 
228 To confirm that plant residues had a higher binding ability than clay, we

229 separated plant residues and clay from the sediment of the Midori River and compared

230 the cellulase binding abilities. Results indicate that the plant residues exhibited

231 approximately 36 times higher cellulase binding than clay. These findings strongly

232 suggest that plant residue functions as an efficient binder of cellulase in the sediment.

233 Overall, this is the first study to demonstrate that sediments composed of clay

234 and plant residues bind cellulase and act as a bioreactor independent of organisms. We

235 are now identifying the organisms that secrete cellulases and will report these results in

236 the near future.

237

\section{Acknowledgement}

239 This study was partly supported by a Grant-in-Aid for Scientific Research from the

240 Ministry of Education, Culture, Sports, Science and Technology of Japan (No.

$24121380131)$.

242

243 References 
244 1. Byrne KA, Lehnert SA, Johnson SE, Moore SS (1999) Isolation of a cDNA

245 encoding a putative cellulase in the red claw crayfish Cherax quadricarinatus. Gene $246 \quad 239: 317-324$

247 2. Guo R, Ding M, Zhang SL, Xu GJ, Zhao FK (2008) Molecular cloning and

248 characterization of two novel cellulase genes from the mollusk Ampullaria crossean.

$249 \quad$ J Comp Physiol B 178:209-215

250 3. Nikapitiya C, Oh C, Zoysa MD, Whang I, Kang DH, Lee SR, Kim SJ, Lee J (2010)

251 Characterization of beta-1,4-endoglucanase as a polysaccharide-degrading digestive 252 enzyme from disk abalone, Haliotis discus discus. Aquacult Int 18:1061-1078

253 4. Sakamoto K, Touhata K, Yamashita M, Kasai A, Toyohara H (2007) Cellulase

254 digestion by common Japanese freshwater clam Corbicula japonica. Fish Sci

$255 \quad 73: 675-683$

256 5. Nishida Y, Suzuki K, Kumagai Y, Tanaka H, Inoue A, Ojima T (2007) Isolation and

257 primary structure of a cellulase from the Japanese sea urchin Strongylocentrotus

$258 \quad$ nudus. Biochimie 89:1002-1011

259 6. Hyde KD, Jones EBG, Leano E, Pointing SB, Poonyth AD, Vrijmoed LLP (1998)

260 Role of fungi in marine ecosystems. Biodivers Conserv 7:1147-1161

261 7. Watanabe H, Tokuda G (2010) Cellulolytic systems in insects. Annu Rev Entomol $262 \quad 55: 609-632$

263 8. Brezmal JA, Brune A (1994) Role of microorganisms in the digestion of 264 lignocelluloses by termites. Annu Rev Entomol 39:453-487 
1

265 9. Watanabe H, Noda H, Tokuda G, Lo N (1998) A cellulase gene of termite origin.

$266 \quad$ Nature 394:330-331

267 10. Niiyama T, Toyohara H (2011) Widespread distribution of cellulase and

268 hemi-cellulase activities among aquatic invertebrates. Fish Sci 77:649-655

269 11. Toyohara H, Park Y, Tsuchiya K, Liu W (2011) Cellulase Activity in meiobenthos

$270 \quad$ in wetlands. Fish Sci in press

271 12. Nelson N (1944) A photometric adaptation of the Somogyi method for the

272 determination of glucose. J Biol Chem 153:375-380

273

274 Figure caption

275 Fig. 1 Correlation between the organic matter content and the cellulase binding ability

276 of the sediments from various rivers. A strong correlation was demonstrated between

277 them $(R=0.66)$. 
Fig. 1

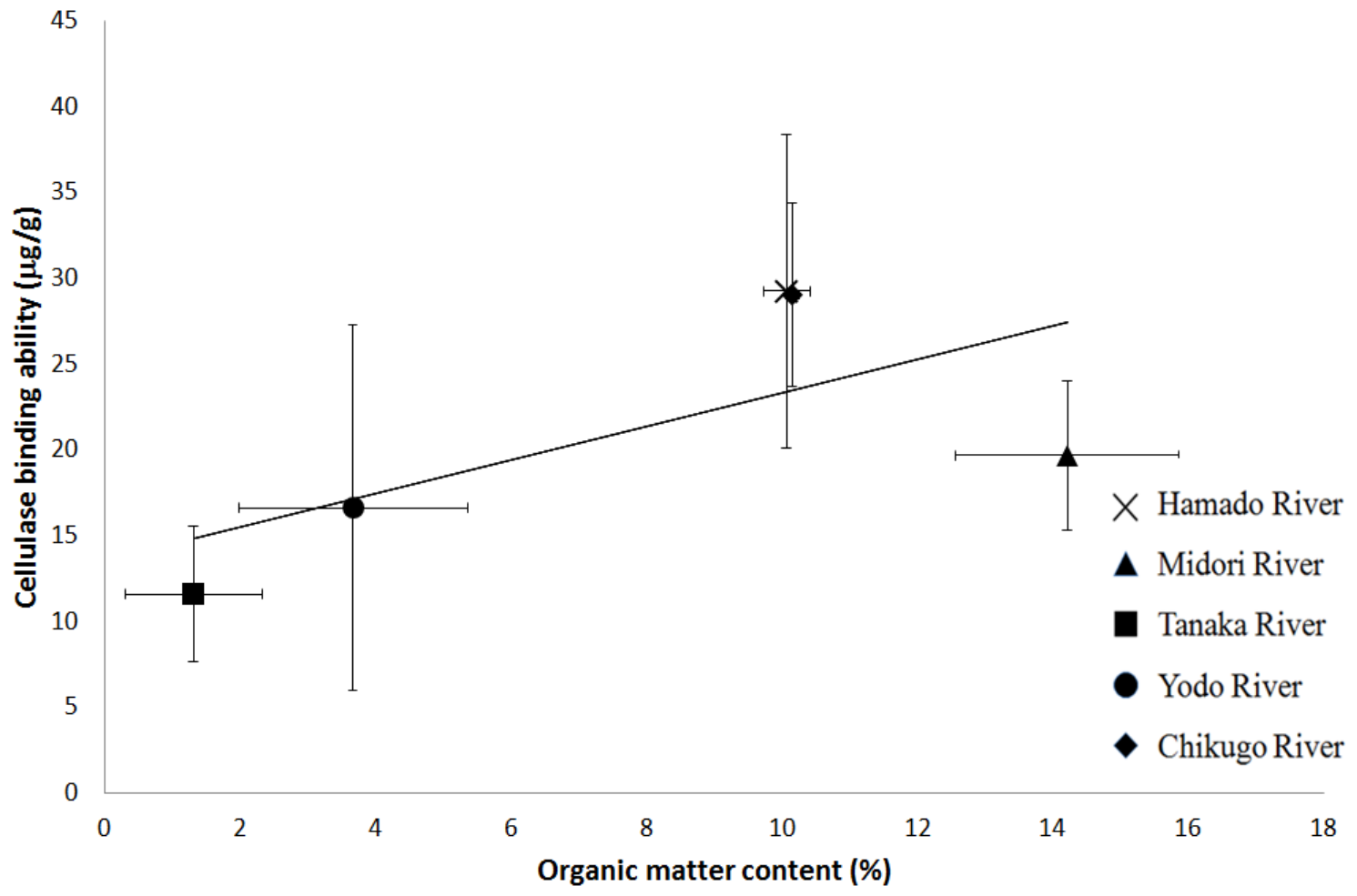


Table 1 Cellulase activity of the sediments collected from five rivers

\begin{tabular}{|c|c|c|c|c|c|}
\hline & Chikugo & Midori & Hamado & Yodo & Tanaka \\
\hline \multicolumn{6}{|l|}{ Collecting sites } \\
\hline & River & River & River & River & River \\
\hline \multicolumn{6}{|l|}{ Cellulase activity } \\
\hline & $59.2 \pm 26.0^{\mathrm{a}, \mathrm{d}}$ & $22.5 \pm 3.4^{\mathrm{b}, \mathrm{c}}$ & $33.6 \pm 8.45^{\mathrm{a}, \mathrm{c}}$ & $77.6 \pm 7.1^{\mathrm{d}}$ & $12.9 \pm 8.2^{\mathrm{b}}$ \\
\hline (nmol/gh) & & & & & \\
\hline
\end{tabular}

Different letters indicate a significant difference $(P<0.05)$. Values are means $\pm \operatorname{SD}(n=$ $3)$. 
Table 2 Effect of Chloramphenicol on cellulase activities of the sediments from Tanaka River and Midori River

\begin{tabular}{|c|c|c|c|c|}
\hline \multirow[t]{3}{*}{ Collecting sites } & \multicolumn{2}{|l|}{ Tanaka River } & \multicolumn{2}{|l|}{ Midori River } \\
\hline & \multicolumn{2}{|c|}{ Chloramphenicol } & \multicolumn{2}{|c|}{ Chloramphenicol } \\
\hline & + & - & + & - \\
\hline $\begin{array}{l}\text { Cellulase activity } \\
\qquad(\mathrm{nmol} / \mathrm{gh})\end{array}$ & $27.4 \pm 1.7^{\mathrm{a}}$ & $43.1 \pm 4.7^{\mathrm{b}}$ & $18.8 \pm 2.0^{\mathrm{a}}$ & $28.3 \pm 7.7^{\mathrm{a}}$ \\
\hline
\end{tabular}

Concentration of chloramphenicol was $40 \mathrm{mg} / \mathrm{g}$ sediment. The statistical analyses on both rivers were performed independently. Different letters indicate a significant difference $(P<0.05)$. 
Table 3 Binding of fungal cellulase to the autoclaved sediments collected from five rivers

\begin{tabular}{lccccc}
\hline & Chikugo & Midori & Hamado & Yodo & Tanaka \\
Collecting sites & River & River & River & River & River \\
\hline Cellulase binding ability $(\mu \mathrm{g} / \mathrm{g})$ & $29.0 \pm 5.4^{\mathrm{a}}$ & $19.7 \pm 4.3^{\mathrm{b}}$ & $29.2 \pm 9.13^{\mathrm{a}, \mathrm{b}}$ & $16.6 \pm 10.6^{\mathrm{b}, \mathrm{c}}$ & $11.6 \pm 4.0^{\mathrm{c}}$ \\
& & & & & \\
\hline
\end{tabular}

Values are means \pm SD $(n=3)$. Different letters indicate a significant difference $(P<$ $0.05)$ 
Reviewer \#2: The reviewer admits that the manuscript has been improved from the original version; however, there are still many points that should be addressed by the authors.

\section{Materials and Methods}

- L86: $\mathrm{KNaC}_{4} \mathrm{H}_{4} \mathrm{O}_{6} \cdot \mathrm{Na}_{2} \mathrm{O}----\mathrm{Na}_{2} \mathrm{O}$ may be $4 \mathrm{H}_{2} \mathrm{O}$.

-We have corrected it as the reviewer suggested.

- L89: $\mathrm{Na}_{2} \mathrm{HAsO}_{4} \cdot \mathrm{As}_{2} \mathrm{O}---\mathrm{As}_{2} \mathrm{O}$ may be $7 \mathrm{H}_{2} \mathrm{O}$

-We have corrected it as the reviewer suggested.

- L133-L134 --- The reviewer cannot imagine how the authors distinguished clay and plant residues and how separated them using tweezers? Clay may be too small to pick up with tweezers.

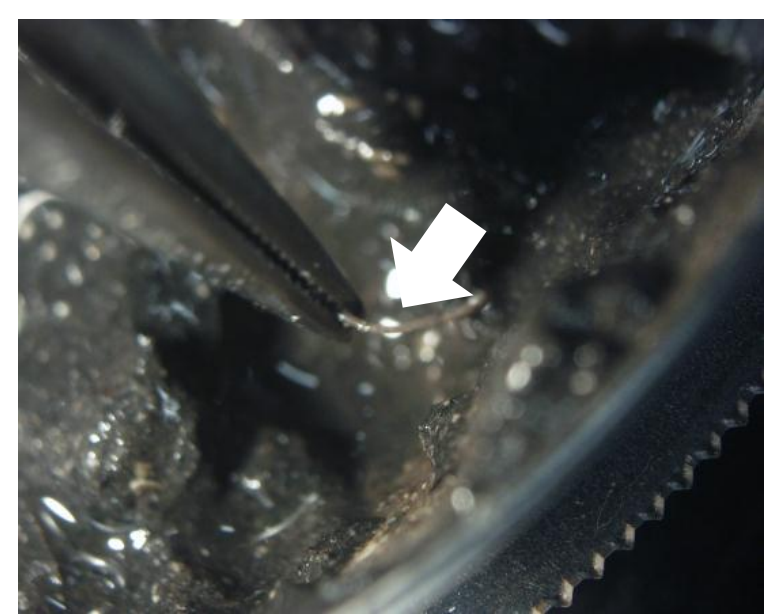

-As shown in the photo, clay and plant could be separated easily by tweezers, because the shapes of them completely different. The arrow indicates a plant residue.

- L136: How many grams of clay and plant residues did the authors use for cellulase-binding assay?

-We used approximately 5g (in wet condition) of clay and plant residues for the assay.

\section{Results}

- L165: exhibited no effect on ... from the Midori River, --- The difference in the cellulase activity between plus and minus chloramphenicol for Midori River 
sample, i.e., 18.8 vs 28.3, indicates that the effect of CP is not negligible. The reviewer cannot agree the authors' explanation "exhibited no effect".

-Because of large SD of minus CP $(28.3 \pm 7.7)$ we could not recognize a significant difference between the values of plus $\mathrm{CP}$ and minus $\mathrm{CP}$ in the Midori River samples. Thus, we considered that $\mathrm{CP}$ exhibited no effect.

- L178: The sediment from Tanaka River showed significantly lower... ---- The revi ewer does not think that the value for Tanaka River is "significantly" low. The val ue for Tanaka River is comparable level with that for Yodo River.

-We would like to show that there is a statistical difference between Tanaka River and Yodo River. We revised as follows to avoid misunderstanding.

Line178-180:"The sediments from Tanaka River showed statistically lower binding ability than those from Hamado River and Chikugo River."

\section{Discussion}

- L203-204: secreted from ... and/or benthic animals ---- Do the benthic animals secrete cellulase to the sediment? Generally, the benthic animals are considered to ingest plant tissues and digest them in the digestive tract with cellulase secreted in the tract.

-We found that cellulases are secreted in feces as active form. We will report this in the next paper.

- L224: the plant residues were completely removed --- How did the authors confir med the "complete" removal of plant tissues.

-It is easy to remove plant residues by tweezers as described above from their shapes. However, as suggested by the referee, it is difficult to declare to be "complete". Thus we revised the sentence as follows in the new manuscript.

L222-225: Organic materials in sediments were considered to be almost entirely a result of plant residues because no weight loss was observed before and after heat treatment of sediments from which the plant residues were removed by tweezers as possible as carefully (data not sown).

- Fig. 1. The values should be presented as the average values with SDs.

-According to the suggestion, we added SDs in the figure.

- Table 1-3. What do "a-d" mean? 
-These alphabet letters show the statistical difference. If the two values are attached by different letters such as "a" and "b", it means both values are statistically different. This expression is usually used to demonstrate a statistical difference between values. For example, please refer Tables 3-8 in the paper published in Fisheries Science 77, 357-365 (2011).

- Table 2. The activities for Tanaka River and Midori River in the absence of chloramphenicol, 43.1 and 28.3, are inconsistent with those in Table 1. How can the author explain?

-We collected sediments from Tanaka River on October 20, 2009 used for the experiment in Table 1, and September 8, 2010 used for the experiment in Table 2. Therefore, the activities in Table $1(12.9 \pm 8.2)$ and Table $2(43.1 \pm 4.7)$ are inconsistent. This is possibly because the slight difference in the collecting sites, difference in the month and/or the difference in weather condition between 2009 and 2010.

As for Midori River, we used the same sediments collected on October 29, 2010 . Thus, no statistical difference was observed; $22.5 \pm 3.4$ (Table 1) and $28.3 \pm 7.7$ (Table 2).

- Table 3. The unit "nmol/gh" is not suitable for indication of "Cellulose binding ability".

-According to the suggestion, we expressed "cellulase binding ability" as the ability to bind the amount of cellulase per one gram weight of dry sediment. To determine the amount of cellulase, we validated the relationship between cellulase activity (absorbance at $600 \mathrm{~nm}$ ) and amount of fungal cellulase $(\mu \mathrm{g})$ as shown below. The amount of cellulase binding to sediment was determined according to the formula inserted in the figure. Cellulase binding ability shown in Table 3 is expressed as the value which was determined by dividing the amount of cellulase by the dry weight of sediment.

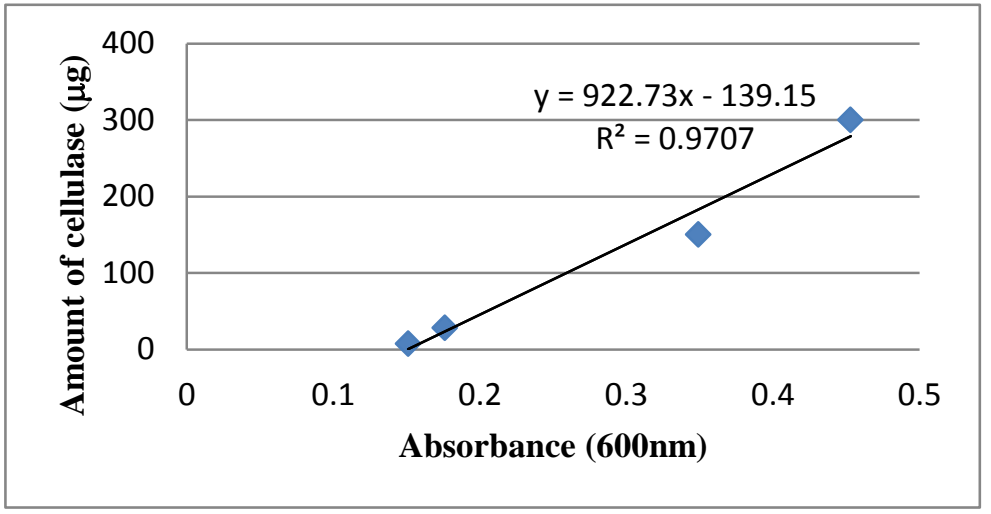

Fig. Relationship between the cellulase activity (absorbance at $600 \mathrm{~nm}$ ) and amount of fungal cellulase $(\mu \mathrm{g})$. 
By this change, the results of statistical analysis in Table. 3 and Fig. 1 were altered. In Table.3, altered portions are shown in red letters as described below.

Table 3 Binding of fungal cellulase to the autoclaved sediments collected from five rivers

\begin{tabular}{lccccc}
\hline & Chikugo & Midori & Hamado & Yodo & Tanaka \\
Collecting sites & River & River & River & River & River \\
\hline Cellulase binding ability $(\mu \mathrm{g} / \mathrm{g})$ & $29.0 \pm 5.4^{\mathrm{a}}$ & $19.7 \pm 4.3^{\mathrm{b}}$ & $29.2 \pm 9.13^{\mathrm{a}, \mathrm{b}}$ & $16.6 \pm 10.6^{\mathrm{b}, \mathrm{c}}$ & $11.6 \pm 4.0^{\mathrm{c}}$ \\
\hline
\end{tabular}

Values are means $\pm \operatorname{SD}(n=3)$. Different letters indicate a significant difference $(P<$ $0.05)$.

In Fig.1, the slope of line was altered. Sentences in the manuscript corresponded were also altered as described below (altered portions are shown in red letters):

Line 26-27: This finding was supported by the fact that there was a strong correlation between the organic matter content in the sediment and the cellulase binding ability $(R=0.66)$.

Line 179-181: ... while those from Yodo River showed lower binding ability than those from Chikugo River.

Line 184-185: The result revealed that $11.7 \pm 2.3 \mu \mathrm{g} / \mathrm{g}$ of cellulase was bound to clay, while $419.5 \pm 47.1 \mu \mathrm{g} / \mathrm{g}$ of cellulase was bound to plant residues.

Line 193-195: A strong correlation between cellulase binding ability and the organic matter content in the sediments was also observed $(R=0.66), \ldots$

Line 210-213: The cellulase activity in sediment from the Midori River was significantly lower than that of the Yodo River (Table 1), although the cellulase binding ability of the sediment from the Midori River was not significantly different from Yodo River (Table 3).

Line 220-222: Indeed, there was a strong correlation between the organic matter content in the sediments and cellulase binding abilities $(R=0.66)$.

Line 230-231: Results indicate that the plant residues exhibited approximately 36 times higher cellulase binding than clay. 
Line 274-277: Fig. 1 Correlation between the organic matter content and the cellulase binding ability of the sediments from various rivers. A strong correlation was demonstrated between them $(\mathrm{R}=0.66)$ 